\title{
THE EFFECT OF DRINKING YOGURT ON THE pH SALIVA OF ELEMENTARY SCHOOL STUDENTS
}

\section{Siti Sulastri ${ }^{\varpi^{*}}$}

\begin{abstract}
ABSTRAK
Saliva menjadi salah satu faktor yang mempengaruhi proses terjadinya karies, karena saliva selalu membasahi gigi geligi sehingga mempengaruhi lingkungan dalam rongga mulut. Saliva berfungsi tidak hanya membantu dalam mengunyah makanan, tetapi juga berfungsi sebagai pelindung. Anak-anak sering mengkonsumsi makanan dan minuman yang mengandung karbohidrat, sehingga bakteri penyebab karies di rongga mulut akan memproduksi asam yang menyebabkan terjadinya demineralisasi. Di antara periode makan, saliva akan bekerja menetralisir asam dan membantu proses remineralisasi. Mengkonsumsi yoghurt dapat menjadi salah satu upaya untuk pencegahan karies pada anak. Yoghurt mengandung kalsium, yang bila dipertahankan lebih lama dalam saliva diharapkan dapat meembantu proses remineralisasi. Tujuan penelitian adalah untuk mengetahui pengaruh minum yoghurt terhadap pH saliva.

Penelitian ini merupakan true eksperiment dengan rancangan Pre and Post Test With Control Group Design. Populasi adalah seluruh siswa kelas I sampai kelas V SD Puluhan Argomulyo, Sedayu, Bantul. Sampel dalam penelitian ini berjumlah 100 siswa dengan menggunakan tehnik random sampling. Analisa data yang digunakan adalah uji Wilcoxon.

Hasil penelitian menunjukkan bahwa sebelum minum yogurt $p H$ saliva 6,80 , sesudah minum yogurt $p H$ saliva 7,44 dengan selisih 0,64. Ada pengaruh minum yogurt terhadap pH saliva siswa Sekolah Dasar Puluhan Argomulyo Sedayu Bantul Yogyakarta $(p=0,005)$.
\end{abstract}

Kata kunci : yogurt, pH saliva

\begin{abstract}
Saliva is one of the factors that influence the process of caries because saliva always wet the teeth so that affect the environment in the oral cavity. Saliva works not only to help in chewing food but also serves as a protector. Children often consume foods and beverages containing carbohydrates, so the caries-causing bacteria in the oral cavity will produce acids that cause demineralization. Among feeding periods, saliva will work to neutralize acids and help the process of remineralization. Consuming yogurt can be an effort to prevent caries in children. Yogurt contains calcium, which, if maintained longer in saliva, is expected to help with remineralization. The purpose of this study was to determine the effect of drinking yogurt on saliva $\mathrm{pH}$.

This research is a true experiment with the design of Pre and Post Test With Control Group Design. The population is all students of class I to class V Elementary School of Argomulyo, Sedayu, Bantul. The sample in this study amounted to 100 students by using random sampling technique. The data analysis used is the Wilcoxon test.

The results showed that before drinking yogurt $\mathrm{pH}$ saliva 6,80, after drinking yogurt $\mathrm{pH}$ saliva 7.44 with difference 0,64. Drinking yogurt can increase saliva $p H$ so that there is the influence of drinking yogurt to $p H$ saliva of Elementary School Student of Argomulyo Sedayu Bantul Yogyakarta $(p=0,005)$.
\end{abstract}

Keywords : yogurt, saliva pH

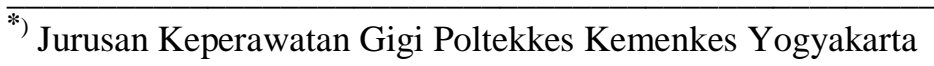

$\bowtie:$ sitislstr7@gmail.com 


\section{PENDAHULUAN}

Usia anak sekolah dasar merupakan masa anak tumbuh dan berkembang dengan sangat pesat. Pertumbuhkembangan tersebut salah satunya tergantung dari pemberian nutrisi yang diberikan oleh orangtuanya. Kualitas dan kuantitas nutrisi yang baik serta benar dapat bermanfaat bagi tumbuh kembang anak. Usia paling rawan adalah usia anak Sekolah Dasar (Sarayati, 2016). Menurut penelitian di negara-negara Eropa, Amerika dan Asia termasuk Indonesia, anakanak dibawah umur 18 tahun terserang karies gigi sebesar $80-90 \%$ (Utami, 2010).

Penyebab karies gigi antara lain karena anak lebih sering mengonsumsi jajanan seperti makanan manis, cereal bar dan biskuit. Ada beberapa anak yang pernah minum minuman ringan ada juga yang minum yogurt. Penelitian suatu lembaga studi di daerah Jakarta Timur mengungkapkan bahwa jenis jajanan yang sering dikonsumsi oleh anak-anak sekolah adalah es sirup dan cilok. Sisa makanan atau minuman dapat membentuk plak yang nantinya akan mempengaruhi $\mathrm{pH}$ saliva dan dapat menyebabkan terjadinya penyakit gigi dan mulut (Maranatha, 2013).

Penyakit gigi dan mulut yang banyak ditemukan di masyarakat adalah penyakit karies dan periodontitis. Karies gigi disebabkan beberapa faktor seperti makanan, bakteri, gigi dan saliva (Sari, 2011). Keadaan saliva yang terlalu asam dalam mulut pada $\mathrm{pH}$ 5,5 akan mengakibatkan demineralisasi kemudian karies gigi. Cara alternatif untuk menanggulangi keadaan yang terlalu asam dalam mulut yaitu dengan mengkonsumsi yoghurt (Maqassary, 2015).

Mengkonsumsi yoghurt dapat menjadi salah satu upaya untuk pencegahan karies pada anak. Bakteri asam laktat seperti species Lactobacillus Bulgaricus dan Streptococcus Thermophilus dalam yoghurt memiliki efek bakterisidal untuk bakteri lain sehingga mengurangi pembentukan plak. Yoghurt mengandung kalsium, yang bila dipertahankan lebih lama dalam saliva diharapkan dapat membantu proses remineralisasai (Purba, 2016).

Salah satu minuman siap saji yang sering dikonsumsi masyarakat adalah yoghurt. Yoghurt memiliki banyak manfaat bagi tubuh manusia, tetapi karena kurangnya informasi dan pengetahuan tentang yoghurt, maka yoghurt dianggap hanya terbatas untuk membantu sistem pencernaan tubuh. Keadaan yang terlalu asam dalam mulut pada pH 5,5 akan mengakibatkan demineralisasi kemudian karies gigi. Karies gigi dan penyakit peridontal merupakan masalah kesehatan masyarakat yang di semua negara di dunia, keduanya menjadi suatu "silent epidemic" yang mengancam anak-anak dan orang dewasa di seluruh dunia (Winarmi, 2014). Cara alternatif untuk menanggulangi keadaan tersebut dan $\mathrm{pH}$ saliva yang terlalu asam dalam mulut yaitu dengan konsumsi yoghurt (Siswosubroto dkk., 2015).

Saliva merupakan salah satu komponen yang memberikan kontribusi terhadap tingkat keasaman $(\mathrm{pH})$ mulut. Saliva sebagai sistem penyangga untuk menjaga $\mathrm{pH}$ optimal mulut, yaitu $\mathrm{pH}$ yang cenderung basa. Jika tanpa saliva, maka setiap makan akan terbentuk lingkungan yang asam yang akan mendukung pertumbuhan bakteri yang merusak gigi. Di dalam saliva juga terdapat ion-ion seperti Kalsium dan Fosfat yang merupakan komponen pembentuk struktur gigi. Fungsi lain dari saliva adalah membantu proses remineralisasi lesi-lesi kecil pada lapisan email gigi (Kusumasari, 2012).

Tujuan penelitian ini ingin mengetahui pengaruh minum yogurt terhadap $\mathrm{pH}$ saliva pada siswa Sekolah Dasar.

\section{METODE PENELITIAN}

Jenis penelitian ini true eksperiment dengan rancangan yang digunakan adalah Pre and Post Test with Control Group Design. Rancangan penelitian sebagai berikut : 


$\begin{array}{lccc} & \text { Pretest } & \text { Perlakuan } & \text { Posttest } \\ \text { Kelompok Perlakuan } & \mathrm{O}_{1} & \mathrm{X}_{1} & \mathrm{O}_{2} \\ \text { Kelompok Kontrol } & \mathrm{O}_{3} & - & \mathrm{O}_{4}\end{array}$

Keterangan :

$\mathrm{O}_{1}$ : pengukuran $\mathrm{pH}$ saliva awal kelompok perlakuan

$\mathrm{X}_{1}$ : Perlakuan

$\mathrm{O} 2$ : pengukuran $\mathrm{pH}$ saliva akhir kelompok perlakuan

$\mathrm{O}_{3}$ : pengukuran $\mathrm{pH}$ saliva akhir kelompok control

Populasi dalam penelitian ini adalah siswa kelas I - V SDN Puluhan Argomulyo, Sedayu, Bantul Yogyakarta. Sampel penelitian adalah siswa kelas $\mathrm{I}-\mathrm{V}$ yang berumur $7-11$ tahun yang berjumlah 100 siswa. Sampel pada penelitian ini dibagi menjadi 2 kelompok yaitu kelompok perlakuan dan kelompok kontrol. Masingmasing kelompok berjumlah 15 orang. Kelompok perlakuan minum yogurt sebanyak $100 \mathrm{ml}$ dan kelompok kontrol tidak minum yogurt. Pengukuran $\mathrm{pH}$ saliva menggunakan $\mathrm{pH}$ meter.

Data yang diperoleh dari hasil pengukuran $\mathrm{pH}$ saliva responden kemudian dihitung rerata $\mathrm{pH}$ saliva sebelum dan sesudah perlakuan. Uji statitik menggunakan uji Wilcoxon dan Mann Whitney.

\section{HASIL DAN PEMBAHASAN}

Rerata $\mathrm{pH}$ saliva responden sebelum dan sesudah minum yogurt dapat dilihat pada tabel berikut.

Tabel 1. Rerata pH Saliva Responden Sebelum dan Sesudah Minum Yogurt

\begin{tabular}{lccc}
\hline \multicolumn{1}{c}{ Kelompok } & Sebelum & Sesudah & Selisih \\
\hline Minum Yogurt & 6.80 & 7,44 & 0,64 \\
Tidak Minum & 7,16 & 7,30 & 0,14 \\
Yogurt & & & \\
\hline
\end{tabular}

Tabel 1 menunjukkan bahwa nilai $\mathrm{pH}$ saliva pada kelompok perlakuan sesudah minum yogurt mengalami peningkatan. Sebelum minum yogurt 6,80 menjadi 7,44 dengan selisih 0,64, artinya ada pengaruh atau ada perbedaan sebelum dan sesudah minum yogurt terhadap $\mathrm{pH}$ saliva responden. Perbedaan ini disebabkan karena meningkatnya angka $\mathrm{pH}$ saliva responden sesudah minum yogurt. Meningkatnya $\mathrm{pH}$ saliva sesudah minum yogurt karena adanya kandungan probiotik dalam yogurt, probiotik dapat menghambat pertumbuhan bakteri acidogenik penyebab karies gigi, dan meningkatkan $\mathrm{pH}$ saliva, sehingga proses demineralisasi terhambat.

Sesuai juga dengan pendapat Siswosubroto dkk (2015), bahwa penyakit gigi dan mulut banyak ditemukan di masyarakat adalah penyakit karies dan periodontitis yang disebabkan beberapa faktor seperti makanan, bakteri, gigi dan saliva. Keadaan saliva yang terlalu asam dalam mulut pada $\mathrm{pH}$ 5,5 akan mengakibatkan demineralisasi/kelarutan email kemudian terjadi karies gigi. Cara alternatif untuk menanggulangi keadaan yang terlalu asam dalam mulut yaitu dengan mengkonsumsi yogurt.

Adapun kelompok kontrol sesudah dilakukan pemeriksaan $\mathrm{pH}$ saliva yang kedua mengalami peningkatan dari pemeriksaan $\mathrm{pH}$ saliva awal yaitu 7,16 menjadi 7,30 dengan selisih 0,14 . Hasil ini sesuai dengan pendapat Putri dkk (2010) dan Najoan (2012), bahwa peningkatan $\mathrm{pH}$ saliva ini dapat disebabkan oleh beberapa factor antara lain rata-rata aliran saliva, mikroorganisme dalam rongga mulut dan kapasitas buffer saliva.

Berdasarkan uji Wilcoxon bahwa nilai Asymp.Sig $(p)$ sebesar 0,005 $<0,05$ jadi Ho ditolak dan Ha diterima, maka secara statistik menunjukkan adanya perbedaan yang bermakna antara nilai $\mathrm{pH}$ saliva Siswa SDN Puluhan sebelum dan sesudah minum yogurt, artinya ada pengaruh minum yogurt terhadap $\mathrm{pH}$ saliva siswa SDN Puluhan. Semula asam menjadi basa. Setelah minum yogurt, $\mathrm{pH}$ saliva responden berubah dari asam menjadi basa, karena selain mengandung probiotik, yogurt juga mengandung kalsium yang dapat meningkatkan $\mathrm{pH}$ saliva dari asam menjadi 
basa. Penelitian ini sesuai dengan hasil penelitian Purba (2017), yang menyatakan bahwa mengkonsumsi yogurt dapat menjadi salah satu upaya untuk pencegahan karies pada anak. Bakteri asam laktat seperti species Lactobacillus Bulgaricus dan Streptococcus Thermophilus dalam yogurt memiliki efek bakterisidal untuk bakteri lain sehingga mengurangi pembentukan plak. Yogurt mengandung kalsium, yang bila dipertahankan lebih lama dalam saliva diharapkan dapat membantu proses remineralisasai. Proses pemasukan kembali mineral-mineral dalam bentuk ion-ion mineral ke struktur kisi-kisi kristal hydroxyapatit sehingga gigi menjadi kuat dan stabil lagi. Adanya proses remineralisasi, maka terjadinya karies gigi dapat dicegah.

Penelitian ini sesuai dengan penelitian Ilyas dan Phielip (2012) meneliti efek anti bakteri. Yogurt pada suhu yang berbeda secara in vitro menunjukkan bahwa yogurt dengan kandungan probiotik L.Casei yang disimpan dalam suhu $26^{\circ} \mathrm{C}$, memiliki potensi yang lebih besar untuk menurunkan koloni bakteri acidogenik secara bermakna dibandingkan yogurt yang disimpan dalam suhu $4^{\circ} \mathrm{C}$. Bakteri memiliki sifat fisiologis spesifik diantaranya dalam hal suhu pertumbuhan. Suhu terbaik untuk pertumbuhan bakteri disebut suhu optimal. Di bawah suhu minimal atau di atas suhu maksimal, aktifitas enzim akan berhenti sehingga metabolisme dan pertumbuhan sel bakteri akan terganggu bahkan dapat menyebabkan kematian sel.

Dengan minum yogurt dapat mengurangi bakteri acidogenik dalam rongga mulut/saliva. Bakteri acidogenik tersebut penyebab karies gigi yang memetabolisme karbohidrat dan menghasilkan asam serta melarutkan email dan merusak jaringan organik gigi. Ada banyak cara menurunkan jumlah koloni bakteri dalam rongga mulut salah satu cara yang sedang dikembangkan yaitu metode probiotik. Metode ini merupakan metode buatan yang bertujuan untuk mengganti bakteri pathogen dengan bakteri yang tidak membahayakan bagian- bagian tubuh tertentu termasuk rongga mulut. Probiotik yang digunakan dalam industri makanan dan telah terbukti dapat menghambat pertumbuhan bakteri kariogenik terutama menggunakan bakteribakteri asam laktat seperti Lactobacilli dan Bifidobacteria. Salah satu jenis probiotik yaitu yogurt atau susu fermentasi. Secara tradisional, pada pembuatan yogurt digunakan kultur starter campuran Lactobacillus sp. dan Streptococcus thermophilus dengan perbandingan 1: 1.

Penelitian lain yang dilakukan oleh Ilyas dan Phielip (2012), bahwa yogurt terbukti efektif untuk menurunkan jumlah koloni bakteri kariogenik dalam saliva apabila dikonsumsi secara rutin dalam jangka waktu tertentu. Bakteri Lactobacillus yang terdapat dalam yogurt akan berkompetisi dengan bakteri kariogenik / Streptococcus yang terdapat dalam rongga mulut untuk mendapatkan ruang, nutrisi lokal dengan adanya interaksi metabolit. Aksi bakteri probiotik dalam rongga mulut bekerja melalui kombinasi secara local yaitu melekat pada plak gigi dan secara sistemik melalui respon imun dalam rongga mulut. Prinsip kerja dari bakteri probiotik yang terdapat dalam yogurt ini bertujuan meningkatkan pertahanan imun mukosa dan aktifitas makrofag serta meningkatkan jumlah killer cells, sel T dan inferno. Selain itu bakteri probiotik juga mampu melekat pada mukosa oral dan jaringan pada gigi untuk menjadi bagian dalam plak dan bersaing dengan pertumbuhan dari bakteri pathogen.

Menurut Simark-Matson dalam Winarmi (2014), bahwa L.acidophilus memberikan efek penghambatan yang kuat terhadap pertumbuhan Streptococcus mutans. Arezoo dan Rooha (2011) dalam Winarmi (2014), mengatakan Lactobacillus acidophilus sebagai bakteri probiotik menghasilkan berbagai Senyawa organik seperti asam, diacetyl, hidrogen peroksida, dan bakteriosin atau bakterisida protein dapat menyebabkan penurunan kepatuhan Streptococcus yang mungkin terkait interaksi 
antara bakteri dan dapat mempengaruhi ekologi dalam mulut. Sehingga dengan mengonsumsi minuman probiotik dapat memberikan efek terhadap penurunan risiko karies gigi dan jumlah Streptococcus mutans.

Penelitian lain oleh Bhushan dan Chachra (2010) dalam Winarmi (2014), bahwa beberapa bakteri probiotik bertindak sebagai bakteriosin atau seperti zat penghambat khususnya mencegah pertumbuhan bakteri kariogenik memiliki kemampuan untuk melindungi gigi dan mempengaruhi pertumbuhan plak supragingiva. Pengurangan adhesi dapat menjadi cara yang efektif untuk mengurangi bakteri kariogenik seperti Streptococcus. Pemberian lactobacilli probiotik dalam susu anak-anak di Helsinki, Finlandia mengakibatkan pengurangan terjadinya karies awal. Probiotik bersifat aman untuk dikonsumsi manusia dan peran teraupetiknya memiliki potensi besar untuk mencegah/ mengobati karies gigi dan berpotensi pada gangguan mulut lainnya. Probiotik memperkuat fungsi epitel barier, modulasi sistem imun meningkatkan resistensi terhadap infeksi rongga mulut, modulasi komposisi biofilm, reduksi bakteri kariogenik, manajemen penyakit periodontal, reduksi bakteri pathogen periodontal manajemen karies, antagonis dengan patogen, beragregasi dengan rongga mulut interaksi dengan epitel rongga mulut.

Hasil penelitian ini didukung oleh Darmawan (2015) dan Purba (2017), bahwa saliva merupakan komponen yang memberikan kontribusi terhadap tingkat keasaman $(\mathrm{pH})$ mulut. Saliva sebagai sistem penyangga/buffer untuk menjaga $\mathrm{pH}$ optimal mulut yaitu $\mathrm{pH}$ yang cenderung basa, jika tanpa saliva maka setiap makan ataupun minum minuman yang asam akan terbentuk lingkungan yang asam tempat bakteri perusak gigi berkembang. Di dalam saliva juga terdapat ion-ion seperti kalsium, fosfat yang merupakan komponen pembentuk struktur gigi. Fungsi lain dari saliva adalah membantu proses remineralisasi lesi-lesi kecil pada lapisan email gigi.
Didukung juga oleh Jensen dalam Ilyas (2012) bahwa dalam penelitiannya menggunakan yogurt untuk mengamati penurunan $\mathrm{pH}$ saliva selama 20 menit setelah mengkonsumsi yogurt, didapatkan hasil bahwa yogurt tidak menurunkan $\mathrm{pH}$ saliva sampai melewati batas $\mathrm{pH}$ kritis yaitu 5,5. Sesuai juga penelitian Sonmes dan Aras yang menyebutkan bahwa yogurt tidak mengakibatkan penurunan $\mathrm{pH}$ saliva di bawah 5 , yogurt tidak dapat mengakibatkan demineralisasi email, tetapi dapat mengurangi jumlah koloni bakteri kariogenik.

Selanjutnya dilakukan uji statistik Mann Whitney antara rerata $\mathrm{pH}$ saliva yang minum yogurt dan $\mathrm{pH}$ saliva tidak minum yogurt didapatkan hasil nilai Asymp.Sig sebesar 0,447 lebih besar dari 0,05 jadi Ho diterima dan $\mathrm{Ha}$ ditolak, maka secara statistik menunjukkan tidak ada beda yang bermakna antara nilai $\mathrm{pH}$ saliva siswa yang minum yogurt dengan $\mathrm{pH}$ saliva siswa yang tidak minum yogurt. Kelompok perlakuan $\mathrm{pH}$ saliva sebelum dan sesudah minum yogurt selisih 0,64 , kelompok kontrol $\mathrm{pH}$ saliva selisih 0,14 antara $\mathrm{pH}$ saliva awal dan pH saliva akhir.

\section{KESIMPULAN}

Berdasarkan hasil penelitian yang telah dilakukan dapat disimpulkan bahwa minum yogurt dapat meningkatkan $\mathrm{pH}$ saliva lebih besar dibandingkan dengan yang tidak minum yogurt. Sehingga ada pengaruh minum yogurt terhadap $\mathrm{pH}$ saliva siswa SDN Puluhan Argomulyo Sedayu Bantul $(\mathrm{p}=0,005<0,05)$.

\section{DAFTAR PUSTAKA}

Darmawan, Arif R. 2015. Pengaruh Minuman Susu terhadap $\mathrm{pH}$ Saliva. Skripsi Fakultas Kedokteran Gigi Universitas Sumatra Utara. Medan. 
Ilyas,M., Phielip,C.,2012. Konsumsi Yogurt Menurunkan Jumlah Koloni Bakteri Kariogenik Dalam Saliva Pada Usia Remaja., Makasar Dental Jurnal, Vol.1. No.1.

Kusumasari, N. 2012. Pengaruh Larutan Kumur Ekstrak Siwak (Salvadora persica) terhadap $p H$ Saliva. Program Studi Pendidikan Sarjana Kedokteran Fakultas Kedokteran Universitas Diponegoro Semarang

Maranatha. 2013. Perubahan pH Saliva setelah Mengonsumsi Jajanan. Bandung. repository.pdf . Diakses 19 Oktober 2015).

Maqassary, A.A.,2015., Gambaran Konsumsi Yogurt Terhadap Waktu Peningkatan pH Saliva.

Notoatmodjo, S.,2012. Metodologi Penelitian Kesehatan, Rinekacipta, Jakarta.

Najoan, SB.,2014, pH Saliva Sesudah Menyikat Gigi dengan Pasta Gigi Mengandung Xylitol Dan Perubahan $\mathrm{pH}$, Jurnal e-Gigi (eG). Vol.2. No 2.

Putri, M.H., Herijulianti,E, Nurjanah, N. 2010. Ilmu Pencegahan Penyakit Jaringan Keras dan Jaringan Pendukung Gigi. Bandung: Buku Kedokteran. EGC.

Purba, N.O., 2016, Pengaruh Lama Waktu Mengulum Yogurt Terhadap $p H$ Saliva,Kadar Kalsium dan Pembentukan Plak Anak Usia 12- 14 Tahun.

repository.ugm.ac.id/index.php/mod . Diakses 2 Januari 2017.

Sarayati. 2016., Psikologi Perkembangan Anak Usia Sekolah Dasar-Dunia Anak Indonesia, Artikel, http://repository.unair.ac.id/29636/3/ 14.pdf. Diakses 4 Januari 2017.

Sari, NI Nyoman Gemini. (2011). Permen Karet Xylitol yang Dikunyah Selama Menit Meningkatkan dan Mempertahankan pH Saliva Perokok Selama 3 Jam. Tesis. Program Studi Ilmu Biomedik Program Pascasarjana Universitas Udayana. Denpasar.

Siswosubroto, A. E., Pangemanan, D.H.C., Lema,M.A. 2015. Gambaran Konsumsi Yogurt Terhadap Waktu Peningkatan $\mathrm{pH}$ Saliva, Pharmacon Jurnal Ilmiah Farmasi UNSRAT, vol.4, No. 4, ISNN 238-2493.

Utami NK. 2010. Indeks DMF $\mathrm{T}$ pada Murid-Murid Madrasah Ibtidaiyah (MI) Muhammadiyah Martapura 2010. Dentino Jurnal Kedokteran Gigi; 2(1):1-2.

Winarmi, 2014., Efektifitas Minum Probiotik Yogurt Dalam Menurunkan Jumlah Streptococcus Mutans Pada Plak Gigi Anak Usia 12-14 Tahun. 